AGRARIS: Journal of Agribusiness and Rural Development Research

Vol. 7 No. 1 January - June 2021, Pages: $53-63$

Article history:

Submitted: September $30^{\text {th }}, 2020$

Accepted: December $25^{\text {th }}, 2020$
Abduselam Faris Abadega

Department of Agricultural Economics and Agribusiness

Management, Jimma University, Ethiopia

Correspondence email: abduselamf104@gmail.com

\title{
Potato Market Participation and Its Extents Evidence from Southwest Ethiopia: A Double Hurdle Approach
}

\author{
DOI: https://doi.org/10.18196/agraris.v7i1.9912
}

\begin{abstract}
Potato is an important commodity for livelihood in many parts of Ethiopia. Potato producers in Ethiopia face sophisticated marketing challenges, including inadequate access to market and low amount of marketed surpluses due to subsistence-oriented production of potato. The study aimed to identify factors that determine the market participation and its extents. About 136 potato producers were selected randomly from peasant association found in Dedo Districts of Ethiopia. Quantitative and qualitative data were collected from primary sources. Descriptive and econometric methods of data analysis were used to analyze data from the survey. A double hurdle model was applied to investigate factors affecting market participation and its extents. Results of descriptive statistics revealed that out of the total sample producer, $87.5 \%$ of sample household has participated in the potato market. Age, sex, education, land size allocated for potato, and non-farm income were significantly influencing potato market participation. Age, sex, education (years of schooling), non-farm income, active labor and land allocated for potato influenced smallholder farmers level of market participation.
\end{abstract}

Keywords: Market Participation, Potato, Double hurdle model

\section{INTRODUCTION}

Though agriculture contributes around $42 \%$ of the gross domestic product (GDP) and about $85 \%$ of Ethiopian people's gains their livelihood directly or indirectly from agriculture, the sector has been characterized with low input, low-value and subsistence-oriented, and is vulnerable to frequent climatic shocks (CSA, 2015; UNDP, 2011). Globally, potato is considered as an important component of agriculture and the third most important food crop in the world next to rice and wheat in terms of human consumption. In addition, potato is the number one non-grain food commodity and an economically important crop of the world (Rykaczewska, 2013). As a potential commodity, potato needs to be developed for regional development (Rozaki, 2020). Moreover, potato is an important crop for food security in the world (Kiloes et al., 2019; Maryanto et al., 2018; Wijaya et al., 2020), and also in parts of Ethiopia by virtue of its ability to mature earlier than most other crops at the time of critical food need (Hassen et al., 2015).

In Ethiopia area under potato cultivation were 67,362 hectares and 921,832 tons were produced. Central Ethiopia, Eastern Hararghe, Northwest Ethiopia, South Ethiopia and 
Western Ethiopia are the major potato production areas of Ethiopia, but the majority of production depends on natural rainfall, and smaller proportions of land are supported by irrigation (Ethiopian Late Blight Profile, 2004).

Although potato is expected to have a great role in smallholders livelihood, the Ethiopian potato sub-sector is currently facing low market participation, unfair price for producers due to long market chain dominated by illegal traders who have a relatively strong power (i.e. financial and information), and limited market access difficulty to obtain buyers, furthermore infrastructural problems due to long distance to reach the market place. The participation of farmers in the high-value market is important (Rao \& Qaim, 2013). The key factors contributing to low yield, mostly related to unfair distribution of returns from potato marketing leads farmers to low gain from the product (Emana, 2008; Gebremedhin, Endale, $\&$ Kiflu, 2001). Study area, Dedo District stands first in vegetable production in general and potato in particular. Hence, this study intended in modelling potato market participation and its extents in Dedo Districts of Ethiopia.

\section{RESEARCH METHOD}

\section{Description of the Study Area}

The study was undertaken in Dedo District, one of 22 districts of the Jimma Zone, Oromia regional state, Ethiopia. Dedo District located at a distance of $377 \mathrm{~km}$ from the capital city, Addis Ababa. The agro-ecological conditions consist of highland (47\%), midland (35\%) and lowland (18\%) with altitude that ranges between 800-3,000 meters above sea level. This climatic condition is favorable for potato production.

\section{Sampling Methods and Procedures}

The study applied multi-stage sampling procedures, Dedo District was selected purposively out of 22 districts found in Jimma Zone, since the district is known for the production of potato. The district has 53 rural peasant associations, but only four were randomly selected. One hundred thirty-six sample farmers were selected randomly based on proportional to the population size of the chosen peasant association like in Table 1. Yamane (1967) sample size determination formula was used to calculate the sample size.

$\mathrm{n}=\frac{\mathrm{N}}{1+\mathrm{N} *\left(\mathrm{e}^{2}\right)}$

Where $-n$ was the sample size, $N$ was Potato producers, and $e$ was he acceptable sampling error.

$$
N=1070, n \approx 136 \& e=8 \%
$$

\section{TABLE 1. NUMBER OF HOUSEHOLDS SELECTED FROM SAMPLE PEASANT ASSOCIATION}

\begin{tabular}{lcc}
\hline Name of the peasant association & Number of Potato producers & Sample \\
\hline Geshe & 220 & 28 \\
Garima Gudda & 267 & 34 \\
Sito & 283 & 36 \\
Ilala & 300 & 38 \\
\hline Total & 1,070 & 136 \\
\hline Source: Own design (2016) & &
\end{tabular}




\section{Data Types, Sources and Methods of Data Collection}

The study collected quantitative and qualitative data types, and sources of primary data were potato farmers. Besides the primary data, secondary data were obtained from published and unpublished documents. Primary data was collected from farmers through an interview schedule containing closed-ended and open-ended questions.

\section{Method of Data Analysis}

Both descriptive and econometric methods were employed in analyzing data from the survey. To model market participation and its extents among smallholders potato farmers double-hurdle was proposed. A lot of studies applied the Tobit model (Tobin, 1958) for modelling market participation and its extent, however, very restrictive for econometric reasons, which makes this model unsuitable for certain empirical applications. Tobit model is also statistically restrictive because it assumes that the same set of variables determine both the probability of a non-zero market participation and the level. The main feature of the double hurdle model is that market participation, and the amount of market supplied decisions are determined by separate variables (Jones, 1989). Likewise, this study employed double hurdle model for determining market participation decision of potato producers and amount of potato supplied to the market since market participation decision and amount of potato supplied is influenced by respondent's socio-economic and demographic factors.

The double- hurdle model used for this particular study was specified as follows:

$\mathrm{d}_{\mathrm{i}}^{*}=\mathrm{X}_{1} \beta_{1}+\mathrm{u}_{1} \mathrm{i}$

$\mathrm{u}_{1 \mathrm{i}} \sim \mathrm{N}\left(0, \sigma^{2}{ }_{1}\right)$

$\mathrm{d}_{\mathrm{i}}^{*}= \begin{cases}1 & \text { if } \mathrm{di}^{*}>0 \\ 0 & \text { if } \mathrm{di}^{*} \leq 0\end{cases}$

$\mathrm{y}_{\mathrm{i}}^{*}=\mathrm{X}_{2} \beta_{2}+\mathrm{v}_{2 \mathrm{i}}$

$\mathrm{v}_{2 \mathrm{i}} \sim \mathrm{N}\left(0, \sigma_{2}^{2}\right)$

$\mathrm{y}_{\mathrm{i}}= \begin{cases}1 & \text { if } \mathrm{yi}^{\mathrm{i}}>0 \text { and } \mathrm{di}=1 \\ 0 & \text { if } \mathrm{yi}^{\mathrm{i}} \leq 0\end{cases}$

The subscript $i$ refers to the $i^{\text {th }}$ household, $d_{i}$ is the observable discrete decision of whether or not to sale potato, while $d i^{*}$ is the latent (unobservable) variable of $d_{i} . y i *$ is an unobserved, latent variable (quantity of potato sold), and yi is the corresponding observed variable, actual quantity of potato sold. $\mathrm{X}_{1}$ and $\mathrm{X}_{2}$ represent vectors of explanatory variables. $\beta_{1}$ and $\beta_{2}$ are vectors of parameters to be estimated and $\mathrm{u}_{1}$ and $\mathrm{v}_{2}$ are random errors (Cragg, 1971).

\section{RESULT AND DISCUSSIONS}

\section{Farmers' characteristics by potato market participation}

An independent-samples t-test was used to compare the mean score, on some continuous variable, for potato market participant and non-participant. The result of the analysis can be seen in Table 2. Regarding experience, the participant had an average of 21.1 years of experience in producing, and that of non-participants was 11.94, which show statistical significance at $1 \%$ probability. The average amount of non-farm income earned by 
sample farmers was ETB 2.22, and that of potato market participant and non-participant was $0.24,16.09$ in thousands of ETB respectively. The t-test results were showed a significant mean difference between potato market participants and non-participants at $1 \%$ probability level in terms of non-farm income. This implies that non-participant households had higher non-farm income than the market participant.

TABLE 2. CHARACTERISTICS OF POTATO MARKET PARTICIPANTS AND NON-PARTICIPANTS

\begin{tabular}{lcccc}
\hline Continuous Variables & Participant $(\mathrm{n}=119)$ & Non participant $(\mathrm{n}=17)$ & \multicolumn{2}{c}{ Total $(\mathrm{n}=136)$} \\
\cline { 2 - 5 } & Mean & Mean & & $\mathrm{t}-$ value \\
\hline Age & 48.3 & 48.7 & 48.38 & 0.1329 \\
Experience & 21.1 & 11.94 & 19.95 & $3.6742^{* * *}$ \\
Non- farm income "000" & 0.243 & 16.08 & 2.22 & $7.7847^{* * *}$ \\
Family Size & 7.93 & 9.78 & 8.16 & $3.9796^{* * *}$ \\
Active Labor & 3.79 & 3.12 & 3.707 & 1.5984 \\
Farm Size & 0.42 & 0.11 & 0.39 & $7.951^{* * *}$ \\
TLU & 6.59 & 8.18 & 6.79 & 1.9072 \\
Number of Oxen & 2.07 & 1.176 & 1.96 & $3.8139 * * *$ \\
Extension contact (\#) & 4.98 & 1.23 & 4.5 & $3.4928^{* * *}$ \\
Distance & 9.01 & 26.17 & 11.16 & $-9.9003^{* * *}$ \\
Education & 3.45 & 0.589 & 3.095 & $3.1968^{* * *}$ \\
Lagged Price & 285.6 & 258.5 & 282.57 & $2.8387^{* * *}$ \\
Income from Crop Sale & $12,198.5$ & $3,931.17$ & $11,165.09$ & $10.941^{* * *}$ \\
Income from Livestock sale & $10,583.3$ & $12,092.76$ & $10,772.00$ & -0.672 \\
TG income from farming & $33,849.60$ & $16,023.94$ & $31,621.42$ & 6.575 \\
\hline
\end{tabular}

*** represent significance at the $1 \%$ probability level, and $\mathrm{n}$ is a sample size.

Source: Own computation of survey data (2016)

The t-test result specified that the mean of land allocated for potato production in 2016 was 0.42 for potato market participants, and 0.11 for non-participants. There is a significant difference at $1 \%$ significance level on land allocated for potato between potato market participants and non-participants (Table 2).

Oxen are the primary source of power for plowing and crop management, the average number of oxen owned by the market participant was 2.07 , whereas for non-participant was 1.176. The mean difference in oxen holding was statistically significant at $1 \%$ probability level. Having access to agricultural extension service initiate farmers to be market-oriented. The t-test indicated that the average number of contacts farmers have with extension workers (development agents) at their farm for the market participant was 4.98 and for nonparticipant was about 1.23 days per production year mean difference of frequency of extension contact was statistically significant at $1 \%$ probability level. The average distance that most of the households used to travel to sell their product to the market was about 11.16 kilometers, where is it 9.01 for the market participant, and 26.17 kilometers for nonparticipant households with a statistically significant mean difference between households at $1 \%$ probability level.

It is obvious educated farmers are exposed to technologies that will help them increase production and supply. The mean educational level (grades) of the market participant was 3.45 years, and that of non -participant was 0.589 years, respectively. This study revealed that 
there is a significant difference between market participant and non-market participant in relation to education at $1 \%$ probability level. Regarding last year market price or lagged average market price have an influence on market participation and marketed surplus moreover, lagged prices can stimulate production and thus marketed surplus of potato for the next year. The mean lagged market price of the market participant was ETB 285.6, and that of non-participant was ETB 258.5, respectively. Last-year price of agricultural commodity affects the quantity of produce as well as supplied to the market, if the price is high, the producer supplied more. The analysis of t-test statistics revealed that there was a significant difference in mean of lagged potato price at $1 \%$ significance level between potato market participant and non-participants. The total gross income from farm income sources of sample respondents was ETB 31,621.42, the average farm income of potato market participants were ETB 33,849.64 per year, and the average farm income of the nonparticipants of potato market was ETB 16,023.94 per year. The major sources of cash income were from the sale of other home cereals and livestock sale. There was a significant difference in mean of total gross income from farming at $1 \%$ significance level between potato market participant and non-participants.

Chi-square test is applied when you have two categorical variables from a single population. It is used to determine whether there is a significant association between the two variables. Concerning sex of the sample households, $91.6 \%$ of the market participant were male, and $88.24 \%$ of non-participant was male however, there is no statistically significant difference in sex between participant and non-participant (Table 3).

TABLE 3. CHARACTERISTICS OF POTATO MARKET PARTICIPANTS AND NON-PARTICIPANTS

\begin{tabular}{lcccl}
\hline Dummy variables & Participant (N=119) & Non-participant (N=17) & Total & $\boldsymbol{\chi}^{2}$ Value \\
\cline { 2 - 5 } & Proportion (\%) & Proportion (\%) & & \\
\hline Sex (Male) & 91.60 & 88.24 & 91.18 & 0.2089 \\
Access to Inputs ( Yes) & 42.02 & 11.76 & 38.24 & $5.7645^{* *}$ \\
Access to Irrigation(Yes) & 28.57 & 5.88 & 25.74 & $4.0066^{* *}$ \\
Access to credit (Yes) & 38.66 & 11.76 & 35.29 & $4.71^{* *}$ \\
Access to market information (Yes) & 42.86 & 5.88 & 38.24 & $8.61^{* * *}$ \\
**** $^{* *}$ represent significance at 1\% and 5\% probability level respectively & & & \\
Source: Own computation of survey data (2016) & & & &
\end{tabular}

Since access to agricultural inputs helps to increase productivity and thereby increase production and supply. Amounts of $42.2 \%$ and $11.76 \%$ of the participant and nonparticipant respectively had access to agricultural inputs such as improved potato variety, inorganic fertilizer and chemicals respectively. There was a statistically significant difference in access to agricultural input between participants and non-participant at 5\% probability level (Table 3).

Irrigation enables smallholders to diversify cropping patterns and to switch from lowvalue subsistence production to high-value market-oriented production. The study results revealed that $28.57 \%$ of market participants have access to irrigation and $5.88 \%$ of nonparticipant had access to it there is a statistically significant difference in access to irrigation between participants and non-participant at 5\% probability level. 
The availability of credit service to farmers has its own contribution in enhancing production and productivity of the agricultural product. Credit is an imperative source of financing the agricultural activities of smallholder farmers, but due to religion view, the need for credit was limited to $35.29 \%$ of the sampled households. The chi-square test result indicated that about $38.66 \%$ of potato market participants had access to credit, and $11.76 \%$ of non-participant had access to credit. Access to credit showed statistically significance proportion difference between them at $5 \%$ probability level.

It is clear that market information is a necessary tool for farmers. The price obtained by producer depends on the reliability, source and channels at which market information was obtained. Moreover, farmers marketing decisions are based on market price information, and poorly integrated markets may convey inaccurate price information, leading to inefficient product movement. The proportion of access to market information for potato market participant was $42.86 \%$, and that of non-participant was $5.88 \%$. The chisquare test indicates a significant difference between potato market participants and nonparticipants at $1 \%$ significance level.

TABLE 4. RESULTS OF DOUBLE HURDLE MODEL FOR THE MARKET PARTICIPATION AND MARKET SURPLUS OF SMALLHOLDER POTATO PRODUCERS.

\begin{tabular}{|c|c|c|c|c|c|c|}
\hline \multirow{2}{*}{\multicolumn{2}{|c|}{ Explanatory Variables }} & \multicolumn{3}{|c|}{ First hurdle (Probit) } & \multicolumn{2}{|c|}{ Second-hurdle } \\
\hline & & Coefficients & Standard Error & Marginal effect & Coefficients & Standard Error \\
\hline \multicolumn{2}{|l|}{ Age } & -0.05 & 0.03 & $0.00^{* *}$ & $-0.14^{* *}$ & 0.08 \\
\hline \multicolumn{2}{|l|}{ Sex } & 2.72 & 1.58 & $0.15^{* *}$ & 2.24 & 2.97 \\
\hline \multicolumn{2}{|l|}{ Education (years) } & 0.41 & 0.22 & $0.02^{* *}$ & 0.3 & 0.26 \\
\hline \multicolumn{2}{|l|}{ Non- farm Income } & -0.11 & 0.05 & $-0.01^{* *}$ & -0.05 & 0.09 \\
\hline \multicolumn{2}{|l|}{ Active Labor (A.EQ) } & 0.43 & 0.27 & 0.02 & $1.18^{* *}$ & 0.52 \\
\hline \multicolumn{2}{|l|}{ Land Allocated for Potato } & 4.13 & 2.02 & $0.23^{* *}$ & $23.70^{* * *}$ & 1.77 \\
\hline \multicolumn{2}{|l|}{ Number of Oxen owned } & 0.08 & 0.33 & 0 & 0.94 & 0.89 \\
\hline \multicolumn{2}{|l|}{ Access to Agro input } & 1.83 & 1.18 & 0.1 & 3.13 & 1.8 \\
\hline \multicolumn{2}{|l|}{ Access to irrigation } & 1.81 & 1.76 & 0.1 & 0.02 & 2.16 \\
\hline \multicolumn{2}{|l|}{ Access to Credit } & 2.68 & 1.66 & 0.15 & $4.81^{* *}$ & 1.99 \\
\hline \multicolumn{2}{|l|}{ Lagged price (last year) } & 0.01 & 0.01 & 0 & $0.04^{* *}$ & 0.02 \\
\hline \multirow{2}{*}{\multicolumn{2}{|c|}{$\begin{array}{l}\text { Access to Market Information } \\
\text { Constant }\end{array}$}} & 2.37 & 2.36 & 0.13 & 2.64 & 1.99 \\
\hline & & -5.54 & 3.83 & 0 & -16.08 & 7.69 \\
\hline Number of observation & $=$ & 136 & & & & \\
\hline $\operatorname{LR} \operatorname{chi}^{2}\left(1^{2}\right)$ & $=$ & 75.77 & & & & \\
\hline Prob $>$ chi $^{2}$ & $=$ & 0 & & & & \\
\hline Pseudo R2 & $=$ & 0.7394 & & & & \\
\hline Log-likelihood & $=$ & -13.354147 & & & & \\
\hline
\end{tabular}

\section{A Double Hurdle Results of Potato Market Participation and its Extents}

Double Hurdle model was employed to identify factors affecting market participation and the actual amount of potato supplied. Hence, multicollinearity and heteroscedasticity detection test was performed using appropriate test statistics. IM-test in STATA 13 was used to check for heteroscedasticity and, VIF and CC for multicollinearity. Based on VIF test results for continuous independent variables there is no multicollinearity problem since the mean VIF result is 1.3 for the continuous independent variables, and the CC result shows no strong associations between dummy variables included in the model. The fitness of the model was checked, and the assumption of the null hypothesis that all predictors in the 
regression model are jointly equal to zero is rejected at less than $1 \%$ level of significance. Out of 12 explanatory variables included in the model, about five variables in participation equation (Probit) and five variables in second-hurdle were found to be statistically significant. The variables, sex, age, education, land size allocated for potato and non-farm income were significantly influencing potato market participation. Age, active labor, land size allocated for potato, access to credit and lagged price (last year price) influenced potato marketed surplus by smallholder farmers (Table 4).

Age of the household head: The expected influence of age assumed was positive but survey result showed that age negatively influenced the market participation of potato at $5 \%$ level of significance, keeping other factors constant an increase of one year in age results in $0 \%$ decrease the probability of participating in the potato market and decrease the amount of potato supplied by $14 \mathrm{~kg}$. The negative influence of age indicates that as the household head gets older, it is difficult to engage in the production and marketing of potato due to the bulky nature of the commodity. The result is in line with Lefebo (2016) finding, which indicates that as the household head gets older, carrying the product to the market becomes more difficult, which in turn decreases the probability of the household decision to enter the kocho (Ethiopian food) market. The study results contradict the finding of Gebre (2015) and Yohannes (2015) that indicated that as the age of a farmer increases the probability of participating in the potato market increases. The result is in line with Gessesse (2009) finding, which explained, as the age of the household head increase, the amount of onion sold decreased.

Sex of the household head: Sex of the household head influenced potato market participation positively and significantly at $5 \%$ probability level. Being a male-headed household increases the probability of participating in the potato market by $15 \%$. This implies that the male-headed household head participated more in the potato market than female. The study's finding in line with Sebatta et al. (2014) that suggest sex of household head had a positive and significant impact on potato market participation. Likewise, the result in line with Sigei (2015) that indicated, male-headed households are more marketoriented than female, hence they participate more in the market for pineapple.

The household's education level: Education of household head in years of schooling influenced household's market participation of potato significantly and positively at 5\% probability level. One year increases in household head's educational level increase the probability of participating in the potato market by $2 \%$, other factors being constant. The study's result in line with Ahmed, Girma, \& Aredo (2016) who suggested the education level of household head has a positive impact on the farmers' participation decision in the potato output market. Besides that, this is also in line with Sigei (2015) who suggests that an individual who better at education level is more empowered with the marketing skill and knowledge that will spur individual to participate in the market.

Active labor: As hypothesized active labor influenced market supply of potato positively at $1 \%$ significant level. A unit increase in active labor in the household family results in an increase in potato marketed surplus by 1.18 quintal. Since larger the number of 
active labor in the family helps carry out production and marketing activity, it encourages marketed surplus of potato. The result is in line with Lefebo (2016) that explained a household with large number of active labor supply huge volume of kocho.

Non-farm Income: As hypothesized the influence of non-farm income was negative. The study results showed that an increase in non-farm income decreases the probability of market participation of potato by $1 \%$ level of significance. The study's finding in line with Lefebo (2016) who suggested an increase in non-farm income of kocho producer household leads to a decrease in the probability of participation in kocho market. It is also in line with Yohannes' (2015) findings that described an increase in household head's income from non/off-farm activities decreases the probability of participating in the potato market. Likewise, with finding of Ahmed et al. (2016) that suggests participation in non/off-farm activities had a negative and significant impact on the farmers' potato market participation decision.

Size of land allocated for potato: As hypothesized the size of land allocated for potato production by household head influenced market participation positively and significantly at $5 \%$ significant level. An average increase in one hectare of land allocated for potato production increases the probability of potato market participation of household by $23 \%$. The result in line with the finding of Kaso (2015) that suggested the increase in cultivated land for wheat increases its market participation. Land allocated for potato production by producer influenced marketed surplus positively and significantly at 1\% significant level. An average increase in one hectare of land allocated for potato production increases the marketed surplus by 23.70 quintals. The result is in line with Tola \& Ketema (2014), who suggested that land size allocated for tomato production increases the marketed surplus of tomato increases. Besides that, it's also in line with (Hailu, 2016) who explained the larger the land size allocated for potato production, the larger the quantity of produce, thereby increasing the quantity of produce available for sale.

Access to credit: As hypothesized the influence of credit access on the marketed surplus of potato was positive and significant at $5 \%$. The result revealed that those who have used credit would increase the marketed surplus by 4.81 quintals. The result indicates that credit access strengths marketed surplus of potato. Study result in line with Asale (2012) who suggested access to credit increases the amount of ginger supplied to the market and Alemu (2012) who explained that farmers who have access to credit could diversify their income sources and thus decide to engage in potato marketing.

Lagged price (last year price): It continues variable measured in ETB per quintal a household received last year. As hypothesized the influence of lagged market price was positive. The result shows that as lagged price increases by one ETB, the amount of potato sold increases by 0.04 quintal, keeping other variables. Myint (2003) explained that if prices in one year are bad, farmers will often respond by planting less in the next year, which will lead to lower production and higher prices. 


\section{CONCLUSION AND RECOMMENDATIONS}

\section{Conclusion}

Potato plays a significant role in supporting smallholder farmers' livelihood in many parts of Ethiopia. Smallholder farmers are challenged with a limited market and low marketed surplus due to subsistence potato farming system. The study aimed to identify factors that determine market participation and its extents. The study revealed that out of the total sample producer, $87.5 \%$ of the sample household participated in the potato market. Age of the household head, sex, education, land size allocated for potato and nonfarm income were significantly influencing potato market participation. Age of the household head, sex, education (years of schooling), non-farm income, active labor and land allocated for potato influenced smallholder farmers level of market participation (marketed surplus of potato).

\section{Recommendations}

1. Promoting on-farm education will improve smallholder farmers' market participation. Therefore, the body should improve adult education and training.

2. Initiating land allocation for potato will increase the market participation and the marketed surplus of smallholder potato farmers thus, the concerning government body should create awareness on land allocation.

3. Initiate active family labor engagement in potato production and marketing activities to increase the household's market participation and the marketed surplus of potato. Therefore, the body should increase active labor participation in potato production and marketing.

4. Creating awareness on utilization of non-farm income for production purpose so that farmers can generate income market participation and marketed surplus of potato. Therefore agricultural and market sector leaders should work on awareness creation for the household that engaged in non-farm income activity.

\section{REFERENCES}

Ahmed, Y. E., Girma, A. B., \& Aredo, M. K. (2016). Determinants of Smallholder Farmers Participation Decision in Potato Market in Kofele District, Oromia Region , Ethiopia. International Journal of Agricultural Economics, 1 (January 2017), 40-44. https://doi.org/10.11648/j.ijae.20160102.14

Alemu, Y. (2012). Analysis of vegetable marketing in Eastern Ethiopia: The Case of Potato and Cabbage in Kombolcha Woreda, East Hararghe Zone, Oromia National Regional State. Haramaya University.

Asale, A. (2012). Analysis of production and market channel of Ginger: The case of Kindo Boloso Bombe and Koisha Woredas of Wolaita Zone, SNNPR, Ethiopia. Haramaya University. 
Cragg, J. G. (1971). Some Statistical Models for Limited Dependent Variables with Application to the Demand for Durable Goods. Econometrica, 39(5), 829. https://doi.org/10.2307/1909582

CSA. (2015). Agricultural sample survey time series data for National $\mathcal{E}$ Regional Level Dedo District Agriculture and natural resources office annual report for year 2007/08, Sheiki, Ethiopia. Sheiki, Ethiopia.

ELBP (Ethiopian Late Blight Profile). (2004). Disease impact on the industry, consumers and country Ethiopia.

Emana, B. (2008). Value chain analysis of horticultural crops in Kombolcha Districts of Eastern Oromia Region, Ethiopia. Addis Ababa.

Gebre, H. (2015). Analysis of Potato Value Chain in Hadiya Zone of Ethiopia. Haramaya University.

Gebremedhin, W., Endale, G., \& Kiflu, B. (2001). National potato research program report.

Gessesse, A. (2009). Analysis of Fruit and Vegetable Market Chains in Alamata, Southern Zone of Tigray: The Case of Onion, Tomato and Papaya. Haramaya University.

Hailu, A. (2016). Value Chain Analysis of Vegetables: The Case of Ejere District, West Shoba Zone, Oromia National Regional State of Ethiopia. Haramaya University.

Hassen, A., Worku, A., Tafere, M., Tolla, M., Ahmed, A., Dagnew, S., ... Abebe, T. (2015). Best Fit Practice Manual for Potato Production and Utilization. BDU-CASCAPE working paper.

Jones, A. M. (1989). A Double-Hurdle Model of Cigarette Consumption. Journal of Applied Econometrics, 4(1), 23-39.

Kaso, T. (2015). Market supply and value chain analysis of wheat: the case of Tiyo and Hetosa districts in Arsi, Ethiopia. Jimma University.

Kiloes, A. M., Puspitasari, Syah, M. J. A., \& Udiarto, B. K. (2019). Strategi Pengembangan Usahatani Perbenihan Kentang di Kabupaten Kerinci. AGRARIS: Journal of Agribusiness and Rural Develpoment Research, 5(1), 21-31.

Lefebo, N. (2016). Value chain analysis of Enset (Ensete ventricosum) in Hadiya Zone, Southern Ethiopia. Haramaya Univesity.

Maryanto, M. A., Sukiyono, K., \& Sigit Priyono, B. (2018). Analisis Efisiensi Teknis dan Faktor Penentunya pada Usahatani Kentang (Solanumtuberosum L.) di Kota Pagar Alam, Provinsi Sumatera Selatan. AGRARIS: Journal of Agribusiness and Rural Development Research, 4(1), 1-8. https://doi.org/10.18196/agr.4154

Myint, U. (2003). Agricultural Marketing Information System in Myanmar. Journal of Publishing Co.Plc. 
Rao, E. J. O., \& Qaim, M. (2013). Supermarkets and agricultural labor demand in Kenya: A gendered perspective. Food Policy, 38(1), 165-176.

https://doi.org/10.1016/j.foodpol.2012.11.008

Rozaki, Z. (2020). Carrying Capacity of Agriculture Sector Based on Commodities' Production in Kulonprogo Regency. 5th International Conference on Food, Agriculture and Natural Resources (FANRes 2019), 316-319. Atlantis Press.

Rykaczewska, K. (2013). The Impact of High Temperature during Growing Season on Potato Cultivars with Different Response to Environmental Stresses. American Journal of Plant Sciences, 04(12), 2386-2393. https://doi.org/10.4236/ajps.2013.412295

Sebatta, C., Mugisha, J., Katungi, E., Kashaaru, A., \& Kyomugisha, H. (2014). Smallholder Farmers' Decision and Level of Participation in the Potato Market in Uganda. Modern Economy, 05(08), 895-906. https://doi.org/10.4236/me.2014.58082

Sigei, G., K. Hillary, B., K. Jonah, K., \& O. Timothy, O. (2015). Factors Influencing the Choice of Marketing Outlets among Small-Scale Pineapple Farmers in Kericho County, Kenya. International Journal of Regional Development, 2(2), 1. https://doi.org/10.5296/ijrd.v2i2.6237

Tobin, J. (1958). Estimation of Relationships for Limited Dependent Variables. Econometrica, 26(1), 24. https://doi.org/10.2307/1907382

Tola, M., \& Ketema, M. (2014). Tomato Value Chain Analysis in The Central Rift Valley: The Case of Dugda Woreda, East Shoa Zone, Oromia National Regional State, Ethiopia.

UNDP. (2011). Strengthening National Capacity through Sustainable Increases in Agricultural Production and Productivity.

Wijaya, O., Widodo, Lathifah, R., Rahmawati, N., \& Rubiyanto, C. W. (2020). Household Dietary Patterns in Food Insecurity Areas. AGRARIS: Journal of Agribusiness and Rural Development Research, 6(2), 168-180.

Yamane, T. (1967). Statistics: An Introductory Analysis, 2nd Edition. New York: Harper and Row.

Yohannes, M. (2015). Performance of Vegetable Market: the case of Kombolcha District, East Hararghe Zone of Oromia Regional State, Ethiopia. Haramaya University. 